\title{
Accordion traditions as Cultural Heritage in border regions of Portugal $^{1}$
}

\author{
Tradições de acordeão como patrimônio cultural nas regiões de fronteira \\ de Portugal
}

\author{
Tradiciones de acordeón como patrimonio cultural en las regiones de \\ frontera de Portugal
}

José Andreas Curbelo ${ }^{2}$

\begin{abstract}
This article examines two emblematic musical forms that are found in the border regions of Portugal: chromatic accordion music in the Algarve in southern Portugal, and diatonic concertina music in northern Portugal. The object of this text is to reveal the processes of development and transmission of these border-area traditions, as well as reveal efforts to conceive these traditions as Cultural Heritage, whether it be on a local, national or supranational level, and the motivations of those efforts. The methodology employed in this study involved in situ oral history collection, and field work was carried out in 2019 and 2020 in various communities in the interior of Portugal. A comparison is made of the two case studies, paying attention to the ways in which these traditions have been fomented and projected as being representative of a region or nation, and also paying attention to the role played throughout history by migratory diasporas (provoked by political, economic and demographic factors) in the transformation, resignification, and projection of these traditions.
\end{abstract}

Keywords: accordion; Algarve; concertina; cultural heritage; Portugal

\section{Resumo}

Esse artigo examina duas formas musicais emblemáticas das regiões de fronteira de Portugal: música de acordeão cromático do Algarve no sul de Portugal, e música de concertina diatónica do norte de Portugal. O objeto desse texto é revelar os processos de desenvolvimento e transmissão dessas tradições de fronteira, e também revelar as iniciativas para declarar essas tradições como Patrimônio Cultural, seja a nível local, nacional ou supranacional, e as motivações dessas inciativas. A metodologia utilizada se compõe de coleta de histórias orais in situ, e trabalho de campo foi realizado em 2019 e 2020 em várias comunidades no interior de Portugal. Uma comparação dos dois estudos de caso é realizada, prestando atenção às formas em que essas tradições têm sido incentivadas e projetadas como representações de uma região ou país, e também prestando atenção ao papel das diásporas migratórias (provocadas por fatores políticos, econômicos e demográficos) na transformação, ressignificação, e projeção dessas tradições.

Palavras-Chave: acordeão; Algarve; concertina; patrimônio cultural; Portugal

\section{Resumen}

Este artículo examina a dos tradiciones musicales emblemáticas de las regiones de frontera de Portugal: música de acordeón cromático de Algarve en el sur de Portugal, y la música de concertina diatónica del norte de Portugal. El objeto de este texto es revelar los procesos de desarrollo y transmisión de estas tradiciones fronterizas, y también

\footnotetext{
${ }^{1}$ This paper is part of the research project "Sustainable practices: a study of the post-folklorism in Portugal in the 21 st century" (PTDC/ART-FOL/31782/2017), supported by the Operational Program Competitiveness and Internationalization and the Lisbon Regional Operational Program, in its FEDER/FNR component, and the Foundation for Science and Technology, in its State Budget component (OE).

${ }^{2}$ Mestrando em Memória Social e Patrimônio Cultural; Universidade Federal de Pelotas; Pelotas, Rio Grande do Sul, Brasil; curbelo@gwu.edu.
} 
revelar las iniciativas para declarar estas tradiciones como Patrimonio Cultural, sea al nivel local, nacional o supranacional, y las motivaciones de estas iniciativas. La metodología empleada en este estudio incluye la colección de historia oral in situ, y trabajo de campo fue realizado en 2019 y 2020 en varias comunidades en el interior de Portugal. Se hace una comparación de estos dos estudios de caso, prestando atención a las formas en que estas tradiciones han sido incentivadas y proyectadas como representaciones de una región o nación y también prestando atención al papel histórico de diásporas migratorias (provocadas por factores políticos, económicos y demográficos) en la transformación, resignificación y proyección de estas tradiciones.

Palabras claves: acordeón; Algarve; concertina; patrimonio cultural; Portugal

The objective of this paper is to explore the processes of development and transmission of emblematic, accordion-based musical traditions found in the border region of Portugal, explore the dynamics through which they have been construed as regional and national markers of identity, as well as briefly review efforts to declare and manage elements of those traditions as Cultural Heritage - whether it be on a local, national or supranational level - and the motivations behind those efforts. Two musical forms, as found in two specific border locations, are examined: chromatic accordion music in the Algarve in southern Portugal, and diatonic concertina ${ }^{3}$ music in northern Portugal. In addition to being the birthplaces of these border musical traditions, the two regions selected - like many regions in Portugal - have been profoundly marked by processes of migration in contemporary history, which obligates the researcher to include these regions' migratory diasporas in any analysis of these musical traditions, which have come to symbolize Portugal (most specifically Minho and the Algarve) abroad.

In his 2017 article "Dinámicas transfronterizas en la música de acordeón y bandoneón del norte uruguayo" published in RELACult - Latin American Journal of Studies in Culture and Society, the author of this current text analyzed the cross-border dynamics of the rural button accordion and bandoneón tradition of northern Uruguay, primarily focusing on the over one-thousand-kilometer-long border with Brasil. (CURBELO, 2017) ${ }^{4}$ This historical border region, scene of conflict and confluence between the Spanish-speaking and Lusophone worlds for centuries, has its roots in the tumultuous relations between Spain and Portugal throughout modern history, and their repercussions in the global geographies that were claimed by each power. (CARREIRAS ET AL., 2007, p.49-52) Hence, examining traditional musical culture

\footnotetext{
${ }^{3}$ Concertina is a term popularly employed in Portugal to designate the diatonic button accordion, a bellowed aerophone instrument with button keyboards on both the right and left sides. Each button produces two different notes, depending on if the musician is opening or closing the bellows.
}

${ }^{4}$ http://periodicos.claec.org/index.php/relacult/article/view/615/334 
along "La Raya"5 between Spain and Portugal reveals important parallels with popular musical traditions in regions of the Americas where Spanish-speaking and Lusophone populations have also been juxtaposed in shared, adjoining geographies.

The historical importance of the Luso-Spanish border has ramifications in the development and projection of cultural and national identities in the Americas - in which music has also played a role. The conflict and confluence throughout the centuries along this border on the Iberian Peninsula created cultural legacies that were posteriorly carried to the Americas in the colonization process and though trans-Atlantic emigration.

Aside from these historical roots, another justification for the author to shift his focus from southern South America to Iberian border regions is the direct connection the two geographies have shared through the phenomenon of migration. The vast wave of emigrants that emanated from Spain and Portugal in the $19^{\text {th }}$ and $20^{\text {th }}$ Centuries to reach countries such as Argentina, Brazil, and Uruguay, provoked profound societal and economic changes on both sides of the Atlantic. In the realm of popular music traditions, new musical forms and instruments arrived from Spain and Portugal, and return migration to Europe carried with it musical forms and cultural expressions from southern South America. The River Plate region, the Brazilian southeast and the Iberian Peninsula were all key nexuses within the maritime Atlantic world of trade, and must be analyzed concomitantly, especially when dealing with fluid cultural movements such as that expressed in popular musical traditions.

The methodology employed in this study involved in situ oral history collection, and field work was carried out in 2019 and 2020, through the Programa Institucional de Internacionalização CAPES PrInt-UFPel, in various communities in the interior of Portugal. Events such as rural dances, holiday performances, group music lessons, festivals, and informal family music performances were documented with digital video and audio from November 2019 to March 2020, and July 2020 to October 2020. In the Algarve, field work was focused around the border town of Castro Marim (divided from Andalucía by the Guadiana River). In northern Portugal, field work was carried out in Valença do Minho which is divided from Galicia by the Minho River. [Figure 1] Interviews were also carried out with accordion manufacturers in central Portugal in the town of Ferreira do Zêzere. Bibliographic research was done in local institutions of memory such as municipal libraries, university archives and historical museums.

\footnotetext{
${ }^{5}$ Popular term used to refer to the Portuguese-Spanish land border, the oldest existing border in Europe, which measures more than $1200 \mathrm{~km}$.
} 


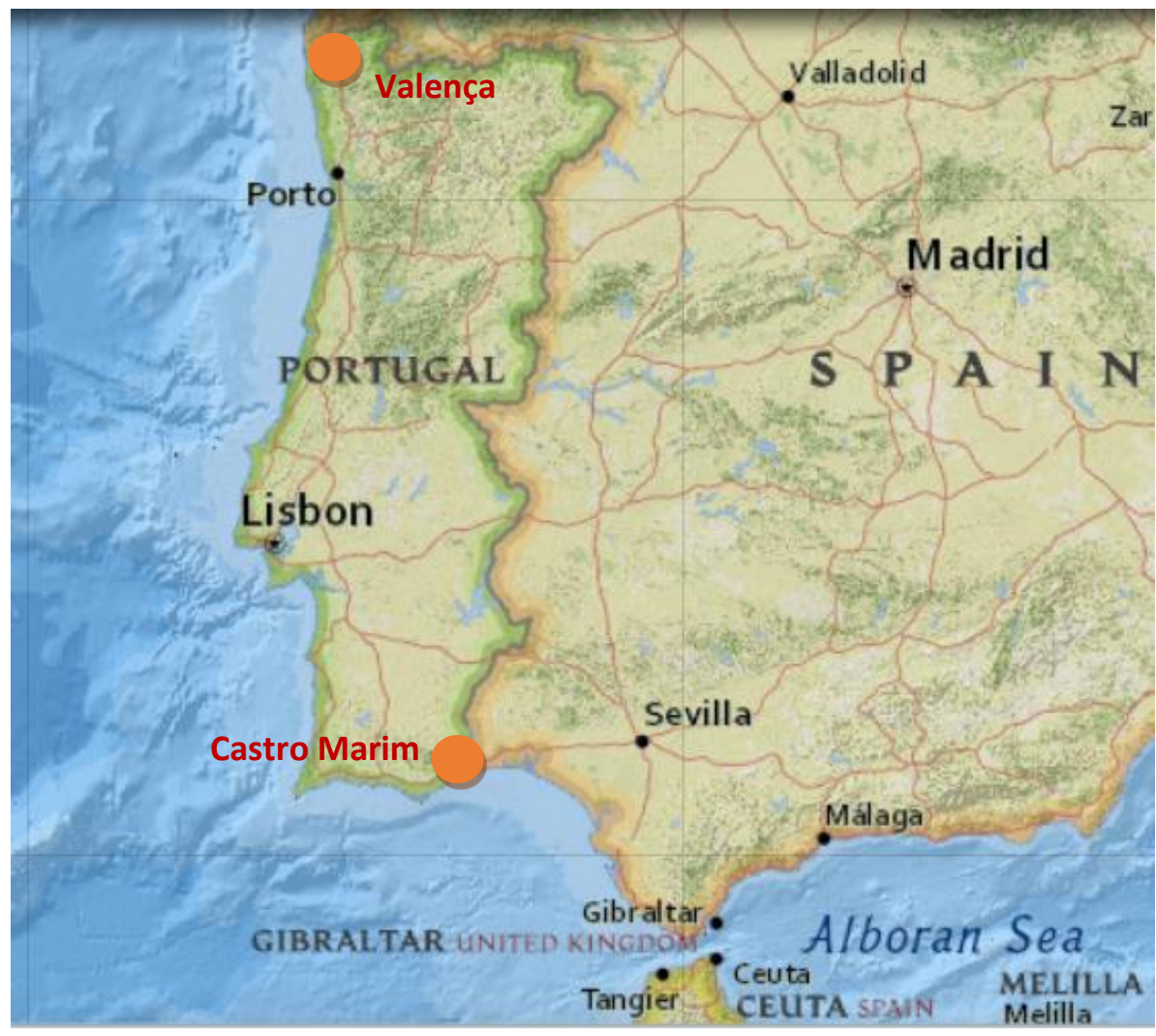

Figure 1 - Map denoting border regions described (Source: NatGeo MapMaker Interactive)

In this text, both case studies are presented, briefly describing the historical background and socio-political character of both border regions, as well as summarizing the history and development of both musical traditions, centered around free-reed instruments. The article attempts to briefly portray the current state of each tradition and their primary methods of transmission, as well as identify measures to declare and manage each tradition as Cultural Heritage. In each case, the relation of the selected musical tradition to its region's migratory diaspora is examined.

Finally, discussion is carried out and a comparison is made of the two case studies, paying particular attention to the ways in which these traditions have been fomented and projected as being representative of a region or nation, and also paying attention to the role played throughout history by migratory diasporas (provoked by political, economic and demographic factors) in the transformation, resignification, and projection of these traditions.

The border between Spain and Portugal is the oldest existing national border in Europe and also one of the continent's longest in extension. The process of its definition dating from the Early Middle Ages, this border is just one expression of the political partitioning the Iberian 
Peninsula has seen since Antiquity, with human presence in the Peninsula dating from the Paleolithic era.

Various civilizations have laid claim, governed, and left their cultural imprint in this region throughout the millennia, among them: Phoenicians, Romans, Visigoths, as well as the Moors who began to dominate the Peninsula beginning in the $8^{\text {th }}$ Century A.D. The resistance and process of military "reconquest" carried out by Christian kingdoms in the north of the Peninsula culminated in 1249 for Portugal in the taking of Faro from the Moors, and for Spain in 1492 with the victory over the kingdom of Granada.

Medina García describes the role that the centuries-long process of Reconquest, from north to south, played in the formation of the borders between what would eventually become the nations of Portugal and Spain:

The Reconquest of the peninsular territory on which those Christian kingdoms embarked, marked the end of a long, drawn-out process of expansion, redefinition, and consolidation of land borders, not always linear and generally unpredictable. (MEDINA GARCÍA, 2006, p.714)

The process of definition of borders between Portugal and its Spanish neighbors proved to be formative of the character of Portuguese sovereignty and its world-view. According to Calderón Vázquez:

In the case of Portugal, the demarcation of borders implied its entrenchment as a sovereign political entity against its powerful and aggressive Castilian neighbor, from there the border appears as a decisive vehicle in the construction of Portuguese national identity and as an instrument that guaranteed its security and territorial integrity. (CALDERÓN VÁZQUEZ, 2015, p.70)

Calderón Vázquez goes on to describe the historical legacy of the role of the LusoSpanish border in Portugal's culture, with Spaniards being construed as "the Other", a division later perpetuated in the Americas as well:

It cannot be forgotten that the Luso-Spanish border emerges as a very clear dividing line between Spain and Portugal, becoming entrenched over the centuries, playing a key role in the process of the generation of Portuguese national identity, in linguistic and cultural terms, as well as emotional terms, and those dealing with social construction, conditioning the vision of "the Other" and their "perception". (CALDERÓN VÁQUEZ, 2015, p.83)

Beyond its conflictive characteristics, the Luso-Spanish border region is by no means uniform, and has also been the setting for innumerable instances of cultural mixture, hybridization, and cooperation, articulated in regional dialects, cultural expressions, fishing practices, centuries-old practices of contraband trade, and other manifestations. From Portugal's border with Galicia in the north to its border with Andalucía in the far south, border 
communities' relations with their immediate neighbors on the other side of La Raya vary greatly.

With the entry of both Spain and Portugal in the European Economic Community in 1986, the centuries-old tradition of each turning their backs on their adjacent peninsular neighbor began to be slowly weakened. (CALDERÓN VÁZQUEZ, 2015, p.76) This also encouraged academic studies on the culture and resources of the border region between the two countries. (NAVAS SÁNCHEZ-ÉLEZ, 2020, p.42) Still, recent studies have shown that, despite efforts to diminish it and ease economic and cultural flows across it, La Raya continues to be a "living historical product" (CALDERÓN VÁZQUEZ, 2015, p.81) that reproduces distinctions between Spaniards and Portuguese and tends to hinder tendencies to develop durable, cross-border identities. (GUALDA ET. AL., 2013, p.13) This dynamic is also reflected in the sphere of traditional music.

\section{- Algarve - Chromatic accordion}

Our first case study is that of the chromatic accordion tradition in the southern Portuguese region of the Algarve, most specifically focusing on the border region with Spain along the lower Guadiana River centered around the historical town of Castro Marim. This strategic border region has been the setting for the presence of numerous civilizations since Prehistory, among them: Phoenicians, Romans, Visigoths, and Moors, that left their mark on this arid region's landscape and culture, and, in the Middle Ages, the fortified town of Castro Marim came to be a key Portuguese bulwark along the Luso-Spanish border, situated across the river from the Andalusian town of Ayamonte.

Currently, the two municipalities are physically connected by fluvial boat service, via the nearby community Vila Real de Santo António, and an international highway bridge running north of each community, which permits the social interaction of the towns' residents. Together, the three towns have joined to form a cross-border Eurocity, in an initiative to further integrate these border communities and foment synergies among them. ${ }^{6}$ Despite further integration, the traditional musical cultures on either side of the river are significantly different, with the chromatic accordion having become crystalized as a symbol of Portugal - most specifically of the Algarve - vis à vis its European neighbors, namely, Spain.

\footnotetext{
${ }^{6}$ This initiative is titled EuroGuadiana 2020 and is recognized by the EU as a European Grouping of Territorial Cooperation (EGTC).
} 
The exact time period and channels of introduction in which the accordion - both its diatonic and chromatic varieties ${ }^{7}$ - arrived in Portugal, and most specifically to the Algarve, are not precise, though it has been documented to be present since the mid to late $19^{\text {th }}$ Century. (CUNHA, 2010, p.110) Various authors associate its introduction (and introduction of the repertoire and styles associated with it: European popular dance music of the $19^{\text {th }}$ Century such as polkas, waltzes, mazurkas, etc.) with the interconnectedness the Algarve has had with other European nations and the presence of other European nationalities in the region. (PASCOAL SINTRA, 2016, p.42) (RAIMUNDO, 2015, p.193-194) Many associate the instrument's growth in popularity in the region with the period after the First World War, a conflict that saw many Portuguese participate as combatants in France, a country where the chromatic accordion was in vogue. (CAMPOS INÁCIO, 2016, p.26) Some of these combatants were musicians themselves, as was the case of famous accordionist José das Neves Vargues (known as José Ferreiro Pai) (1895-1967) who returned from the conflict with musical experience acquired in France. (GUERREIRO, CONCEIÇÃO, 2014, p.21)

The chromatic accordion began to be widely incorporated in rural dances or bailaricos throughout the Algarve (often accompanied by percussion, such as the metal triangle called "ferrinhos") where the dance repertoire consisted of traditional round dances, as well as local adaptations of urban European salon dance music from the $19^{\text {th }}$ Century (schottische, polka, etc.) such as the local, late- $19^{\text {th }}$ century creation: corridinho. (RAIMUNDO, 2015, p. 192) These bailaricos served as moments of socialization and ludic activity for rural communities in the interior of the Algarve, many without electricity at least until the 1960's. [Figure 2]

\footnotetext{
${ }^{7}$ The diatonic button accordion, referred to in Portugal as concertina (whose characteristics were described in an earlier footnote), is the predecessor of the chromatic accordion, a variety of accordion which possesses three to five rows of buttons on the right hand, each button producing the same note whether the accordionist is opening or closing the bellows.
} 


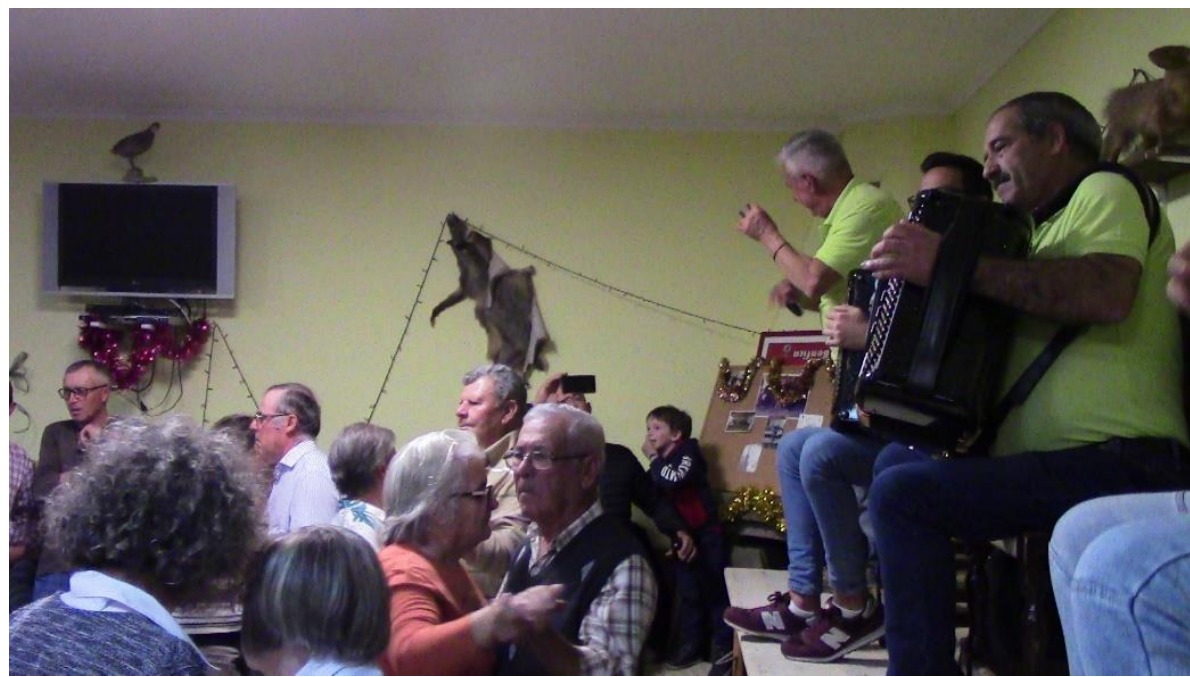

Figure 2 - Grupo Mato Bravo (Quebradas, Castro Marim, 2019)

For generations, the tradition of accordion performance in the Algarve was primarily transmitted orally from one generation to the next within families. (CAMPOS INÁCIO, 2016, p.30) A quintessential example of this phenomenon is the case of the Pereira family from the rural areas of the border municipality of Castro Marim. The accordion tradition in the family begins with Francisco Venâncio Pereira (b.1921) in the rural locale of Fonte do Penedo (just a few kilometers from the fluvial border between Portugal and Spain along the Guadiana River). Having learned to play by ear, he performed dances in the Sotavento algarvio ${ }^{8}$ and Baixo Alentejo. (CAMPOS INÁCIO, 2016, p.84) At times he would play dances with his son, accordionist Miguel Pereira (b.1949), also born in Fonte do Penedo, alternating so that neither would tire out during the night. (PEREIRA, M., 2019) Miguel's son, João Pereira (b.1976) complemented the methods of playing by ear and self-training - as practiced by his father and grandfather - with a formal musical education, eventually studying at the Conservatory in the city of Faro. (PEREIRA, J., 2020)

Throughout the $20^{\text {th }}$ century, without losing its original essence, the chromatic accordion tradition of the Algarve expanded from its roots as accompaniment of regional social dances and popular culture festive traditions to include the phenomenon of formally-trained concert soloists interpreting advanced classical and international repertoire (as well as repertoire from the Algarve) in the context of global competition circuits. This came to be through the continuation of the trans-generational accordion lineage of the Algarve through the successful and widely-publicized professional careers of influential Portuguese accordionists, such as Eugenia Lima (1926-2014), as well as the engaged and committed work of educators who have

\footnotetext{
${ }^{8}$ The eastern half of Algarve.
} 
formed the newest generations of accordionists, and organized new public venues to showcase them, as this tradition moved into the $21^{\text {st }}$ century. All this has contributed to consolidate the chromatic accordion as a cultural symbol of the Algarve, an identity projected abroad, but also held by many people from, and with roots in, the Algarve.

Due to the Algarvian migratory diaspora, accordionists from the region have enjoyed global mobility in their artistic careers (Canada, United States, Argentina, Angola, France, Brazil, etc.), performing wherever migratory communities have organized themselves and seek to reconnect and strengthen emotional ties of Identity and Memory with their places of origin through cultural symbols that represent them - in this case, the chromatic accordion (and the socializing practices centered around it).

Though the Portuguese presence in the River Plate region dates from the colonial period, by the late $19^{\text {th }}$ century a new wave of Portuguese emigrants began to arrive. (CARREIRAS ET AL., 2007) By the first decades of the $20^{\text {th }}$ century, emigrants from the Algarve (eschewing the traditional Portuguese migration destination of Brazil) made up the most significant segment of Portuguese migrants in Argentina, a primary destination for European migration in that period. (BORGES, 2009, p.11)

Attracted by relatively higher wage levels, and amplified as personal, family, and village networks were established in the new country, Algarvian emigration to Argentina in the $20^{\text {th }}$ century left a mark on the communities of origin back home. Referred to as "terra dos esquecidos" (Land of the Forgotten) in reference to the amount of emigrants that eventually did not return to the Algarve, Argentina is the home of Algarvian emigrant collectivities that, nonetheless, have maintained affective ties with their local communities of origin. Researcher Marcelo Borges (2009, p.20) states, "Migration was firmly rooted in the local ground. More than a national phenomenon, the move of tens of thousands of Portuguese migrants to Argentina originated in, and achieved full meaning, at the level of the aldeia (village)".

José Manoel Aniceto (b.1953), from the village of Bordeira (Santa Bárbara de Nexe), who grew up listening to stories of Argentina and Brazil from his uncles who had emigrated there as young men in the early $20^{\text {th }}$ century and returned to Portugal, illustrates the abovedescribed dynamics in his description of the type of diasporic family and community relations that has culturally bound together far-flung migrant populations, in this case, in the River Plate region:

I have an aunt in Argentina. I have an aunt and first cousins in Argentina, they never returned. They created lives for themselves there, far away, they went away for good. However, they remain connected to Bordeira to this day. For example, my cousins are involved with an association in Buenos Aires, Argentina, a Portuguese association, they have a rancho folclórico. Sometimes they bring accordionists [...], many 
accordionists from Portugal [...] These emigrant associations stay connected to their village, their home, their families, and from there they foment international tours of these artists, Portuguese artists, and from Bordeira. From Bordeira they primarily bring accordionists. Bordeira has always had good accordionists, and still does. (ANICETO, 2020)

The collective work of Algarvian professional accordionists and educators, many with international careers, gave fruit in 2012 with the creation of the group Mito Algarvio Associação de Acordeonistas do Algarve in Castro Marim. Founded by important artists and teachers from the region, Mito Algarvio is dedicated to imparting instruction, organizing regular showcases and galas, as well as collaborating on an international level - in representation of Portugal - in the activities of Confédération Internationale des Accordéonistes, part of the International Music Council, which is a consultative body of UNESCO.

Accordionist and educator João Pereira, member of Mito Algarvio, describes how his experience teaching students (several of whom go on to compete internationally) stems from his background of inter-generational transmission within a family structure, so common in the Algarvian accordion tradition [Figure 3]:

Music was the bond that united the family. Any family gathering began and ended with music. In my family environment, I was born surrounded by accordion music, because of my dad, because of my grandpa. [...] Music has a social factor [...] music enables you to develop capacities that other activities don't. [...] Music transmits many things [...] I believe it plays a fundamental role on a psychological level (for students). (PEREIRA, J., 2020)

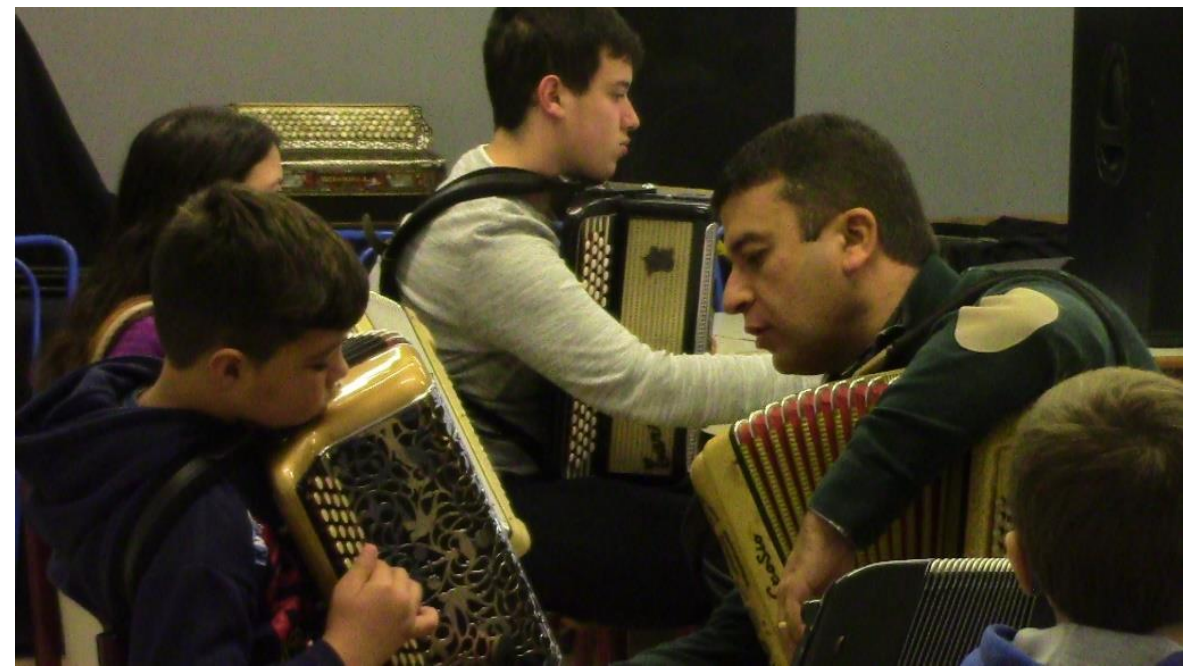

Figure 3 - João Pereira giving classes at Mito Algarvio (Altura, Castro Marim, 2019) Photo: José A. Curbelo

Pereira goes on to describe his work as an accordion educator in the Algarve, most specifically within the context of the border region with Spain and the juxtaposition of Andalusian and Algarvian cultures:

I have taught an innumerable number of students, even Spanish students. Just recently, there is interest (in the accordion) in Andalusia, it used to be little known in Spain, they just had the guitar. [...] Here in southern Spain there isn't an accordion culture. 
Here we live in a region of Portugal where the accordion is most popular, but if you cross the border there is no vestige of the accordion, only guitar is what was played. The difference between Spanish and Portuguese students is curious, it is much easier for the Portuguese students because they form part of the culture, they have more familiarity with the instrument. [...] Its easier for them than the southern Spanish students. (Portuguese students) were born into this culture and they (Spanish students), no, they were born into a culture different from ours. They have a completely different style. (PEREIRA, J., 2020)

Reinforcing the chromatic accordion's status as an internationally-recognized emblem of the Algarve, a conception that has been projected at least since the 1930's, Pereira identifies the factors that distinguish Algarvian accordionists:

It is in the Algarve where the (accordion) tradition is strongest in Portugal, where the accordion has wider projection. It is easy to distinguish the style of an Algarvian accordionist from that of an accordionist from another region. Here, Algarvian accordionists have a unique soul that other regions don't have. Here there is sweetness, and flavor [...] perhaps because of the great cultural exchange that we have in the Algarve with people from other countries, maybe all that contributed to this, to what we call "Alma Algarvia" (Algarvian Soul). (PEREIRA, J., 2020)

Though not officially declared as Cultural Heritage ${ }^{9}$ by the Portuguese Government's Direção-Geral do Património Cultural nor as Intangible Cultural Heritage by UNESCO (unlike other Portuguese traditional expressions such as Fado or polyphonic singing from Alentejo) ${ }^{10}$, the accordion tradition in the Algarve - most specifically that of the accordion epicenter, Bordeira, a village within the parish of Santa Bárbara de Nexe near Faro, the district capital is considered intangible cultural heritage by the consortium of regional museums: Rede de Museus do Algarve, through its working group dedicated to Intangible Cultural Heritage (RMAPCI). ${ }^{11}$ Being the subject of a 2012 exhibition at the Museu Municipal de Faro, the chromatic accordion tradition of Bordeira has produced many notable accordionists, composers, and educators that have been widely influential in the Algarve, Portugal and internationally. ${ }^{12}$

The popular musical and dance expressions of the Algarve have been employed by public authorities to represent the region and the nation at least since the 1930's, a period when Salazar's Estado Novo followed nationalist tendencies in vogue in Europe and the Americas in creating its own conceptions of Cultural Heritage and Folklore and the processes of their

\footnotetext{
9 "Patrimônio Cultural" in Portuguese

${ }^{10}$ https://unescoportugal.mne.gov.pt/pt/temas/proteger-o-nosso-patrimonio-e-promover-acriatividade/patrimonio-cultural-imaterial-em-portugal

${ }^{11}$ https://algarveimaterial.wordpress.com/acordeao-da-bordeira/

12 https://cms.cmfaro.pt/upload_files/client_id_1/website_id_1/museu/A\%20tradicao\%20do\%20acordeao\%20em\%20Bordeira.pd $\underline{\mathrm{f}}$
} 
investigation, usage, and projection in the legitimation and perpetuation of the regime's corporativist, authoritarian vision. (RAIMUNDO, 2015, p.184) (MARQUES ALVES, 2010, p.191) (SARDINHA, 2001, p.18) Though the phenomenon predates the Estado Novo (19261974), the organization and performance of Portuguese traditional music and dance troupes: "ranchos folclóricos" was actively supported by Salazar's government throughout the regime. (EL-SHAWAN CASTELO BRANCO \& FREITAS BRANCO, 2003).

Serving to mobilize the populace of the nation's rural interior (Ibid., p.9), the process of "folklorization" and its projection of "national identity" was primarily directed at Portugal's middle and upper classes, as well as the nation's foreign peers within the international sphere. (MARQUES ALVES, 2010, p.190) Under the Estado Novo, this movement projected an image of a pacific, rural nation, lacking any class conflicts, content with the nationalist authoritarian regime imposed on it. Sardinha summarizes:

\begin{abstract}
What the Estado Novo did in relation to the so-called folkloric movement was, in general, what $20^{\text {th }}$ century European authoritarian regimes did: appropriate or emphasize the aspects of nationalist or patriotic character that could be transported by ranchos folclóricos as portrayers of a mythical, rural purity or of a certain ethnic national identity. (SARDINHA, 2001, p.18)
\end{abstract}

This portrayal also was crafted to influence the attraction of international tourism to Portugal, this dynamic being particularly relevant in the case of the Algarve, a sun-drenched, littoral region. (SOUSA, 2003, p.8). In this light, many ranchos folclóricos and similar groups were sent abroad by the regime to perform in festivals, expositions, and other venues.

In the Algarve, the Grupo Folclórico de Faro was founded in 1930, which, at the time, had the participation of emblematic artists such as accordionist José Ferreiro Pai. (GUERREIRO, H., CONCEIÇÃO, N., 2014, p.22). Their acclaimed performances (and performances of related groups) at showcase events such as the 1932 Exposição Industrial de Lisboa, gained visibility for Algarvian cultural expressions, and the local musical and dance creation, corridinho, came to symbolize the region on national and international stages, a phenomenon that was perpetuated during the Salazar regime. (PEREIRA, 1997, p.94)

Though the historical contexts are very different, it can be observed that perhaps the motivations are similar in projecting an image abroad of Algarvian musical culture defined by the chromatic accordion and the corridinho. Whether with the aim of attracting foreign tourism during the Estado Novo or showcasing Portuguese accordion virtuosi on international stages through activities of Mito Algarvio, presenting the chromatic accordion and its regional repertoire as intangible cultural heritage of the Algarve has proven to be an effective tool in 
forging a visible cultural brand for the region, which, in turn, has enrichened international perceptions of Portuguese national culture vis-à-vis its European neighbors.

\section{- Minho - Concertina}

Focusing our gaze further north, the second case study examined is that of the concertina tradition in northern Portugal. Our analysis is centered around the town of Valença do Minho on the border with Galicia separated from the historic town of Tui by the Minho River, the geographical feature which has woven together human presence in the area for millennia. The lower Minho region has had human presence since the Paleolithic age and numerous cultures have resided, dominated, and left cultural legacies there: Bronze-Age Celtic cultures, Romans, Goths, Suebians, and others.

Founded in the $12^{\text {th }}$ Century, the fortified town of Valença formed part of the Portuguese line of defense against its neighbor, being attacked several times by the Spanish, such as during the Portuguese Restoration War (1640-1668), requiring the Portuguese to further fortify the town. (BLANCO ROTEA \& GARCÍA RODRÍGUEZ, 2005, pp.12-13) By the mid-19 century, after relations between the two nations bettered, a treaty governing this fluvial border was negotiated in 1864 (GARCÍA-ÁLVAREZ \& PUENTE-LOZANO, 2016, p.9) and eventually a metal rail and roadway bridge physically connecting the two towns was inaugurated in 1886. Currently, just as Castro Marim/Vila Real de Santo Antônio/Ayamonte, Tui/Valença together form a Eurocity.

Though many cultural similarities exist, as is the case in the lower Guadiana, the traditional musical cultures on either side of the Minho River are also very different from each other. In Valença, accordion luthier Carlos Pedrosa, founder of the Pedrosini brand of concertinas $^{13}$, highlights his perception that the concertina is not played on the Galician side of the border [Figure 4]:

No, (they play) accordion. Some Galicians come here to tune their (piano) accordions, Galicia has a different tradition, its not the same as ours. There they play the piano accordion ${ }^{14}$ (...) each place has a different system (its always been like that). They are old things that we don't know the reason why, the old people passed away. One plays one way, the other plays another way. No accordionist plays the same as another, just like in soccer, nobody plays the same way. Each artist has their own way, we don't know why, its difficult (to know). (PEDROSA, 2020)

\footnotetext{
${ }^{13}$ https://pt-br.facebook.com/pedrosini.pedrosa

${ }^{14}$ The piano accordion is similar to the chromatic accordion, however possesses a piano keyboard on the right hand as opposed to three to five rows of buttons.
} 


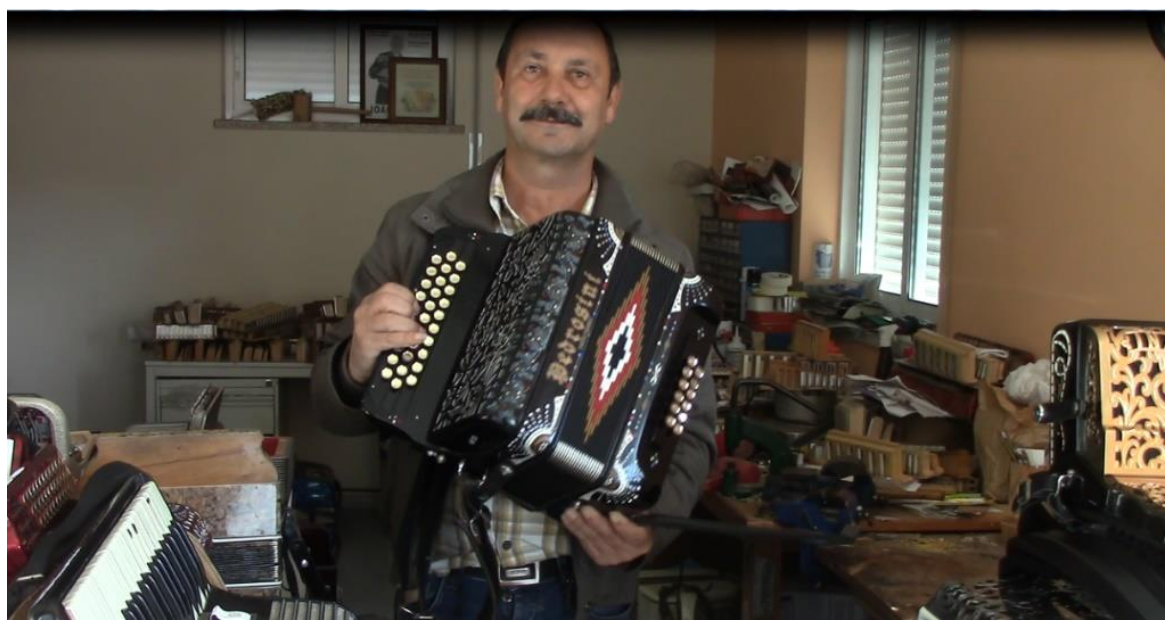

Figure 4 - Carlos Pedrosa in his workshop (Valença do Minho, 2020) Photo: José A. Curbelo

Portuguese researcher José Alberto Sardinha places the introduction of the diatonic button accordion in Portugal in the mid $-19^{\text {th }}$ century, as mentioned earlier in this paper. Originally arriving in its original one-row variety (popularly known in Portugal as "harmónio"), this instrument, and the Central European salon dance music associated with it, rapidly spread amongst the popular social classes of Portugal displacing older dance styles. (SARDINHA, 2000, p.450-451) Later, the diatonic accordions with two and three rows ("concertinas"), were introduced and enjoyed similar popularity throughout the regions of the country from North to South.

In the far northern region of Minho, the concertina served to progressively displace traditional stringed instruments in popular festive events involving music and dance. (SARDINHA, 2001, p.79) However, it also came to symbolize the region's culture, much in the same way that the chromatic accordion came to represent the Algarve in the south. According to Sardinha:

The concertina, for its characteristics: volume, timbre, and being able to coordinate melody $[\ldots]$ with accompaniment, ended up coming to dominate the instrumental panorama of contemporary Minho, and is today, without a doubt, the instrument most preferred by the people of this province. (SARDINHA, 2001, p.79)

The concertina has been traditionally associated with festive, ludic socialization and commensality of members of rural communities in events such as: town dances, popular religious processions and pilgrimages ("romarias"), completion of collective agricultural tasks and carousing in local taverns, all settings that came to conform the instrument's "natural habitat" in Portugal's interior. In the central Portuguese location of Ferreira do Zêzere, accordion constructor and luthier Leonel Carreira Rocha (b.1940), originally from Pombal, comes from a musical lineage - his grandfather played concertina, a talent that was passed on 
to his father via inter-generational oral transmission, an important method of transmission in the concertina tradition. [Figure 5] According to Rocha:

(When we came to Ferreira do Zêzere) my dad brought his concertina and began to play in the bailaricos, at corn-shucking time, at festivals, and he even played in the taverns. People having a few drinks, it was my father who played. [...] (He played) country waltzes, and played at corn-shucking time so people could sing desgarradas ${ }^{15}$. At that time fadinho was already played on the concertina. [...] Everybody had a good time, everybody danced. (ROCHA, 2020)

Luthier Carlos Pedrosa did not come from a musical family and he recalls how he learned to play concertina when he was younger, by interacting with its previously described "natural habitat" (most specifically, at a pillar of village and neighborhood socialization: the local tavern) in localities in Minho such as Valença, Caminha, Ponte de Lima, and Viana do Castelo. Sardinha (2000, p.326) writes, "Taverns effectively played a role much larger than one would think, not just in the social and economic aspects of villages, but also in the field of music". With this in mind, Pedrosa goes on to describe:

(I learned) by listening to the older players, and I went from there. I played in groups with older players and I learned from them. [...] Sometimes we would get together in the tavern to drink wine and play concertina. All of that is part of a learning process, a school. Go to the tavern, drink wine, play concertina, get drunk. The more they drink, the better they play. (PEDROSA, 2020)

Pedrosa also ironically describes the process in which the concertina, a nexus of traditional socialization practices in the region, has risen from its origins among rural popular classes to be contemporarily embraced by a wider segment of the Portuguese population, both within the country and abroad, as the instrument has gained status as a symbol of Minho and the nation as a whole:

People from the villages went to the city and people from the city went to the villages, nowadays everything is (mixed). Before, (concertina players) were drunks from the villages, but now everybody plays. A doctor also drinks. Before it was just the drunk guys from the country, but doctors, lawyers and engineers all drink as well, - so do priests. Before, it was the drunk guys at the tavern who would play concertina. We played, danced and sang. [...] Nowadays, everybody drinks, so everybody plays concertina. Anyone can play concertina. [...] The concertina is a Portuguese tradition that should be supported. (PEDROSA, 2020)

In Ferreira do Zêzere, Isabel Gomes, who has been repairing accordions and concertinas since 1990, reflects on the growth in popularity of the concertina in recent years [Figure 5]:

Here in our region, the concertina is showing up more and more, years ago it was only found in the North, the concertina was found more in the North. It is tending to grow. Practically all over the country you find concertinas, sometimes with groups that are worth forgetting [...] but there are people who play concertina very well. [...] Everybody wants to learn to play concertina by ear. [...] But you can tell when

15 "Cantar à desgarrada" is the Portuguese tradition of duels of sung improvised poetry, commonly accompanied in Minho by concertina. 
someone plays concertina if they learned by reading music or if they learned by ear. It's a shame that, in Portugal, the concertina is starting to become somewhat vulgar; So many people want to play. [...] Before, concertina was used just to play folclore, but there are people who know how to play the concertina very well. (ROCHA, GOMES, 2020)

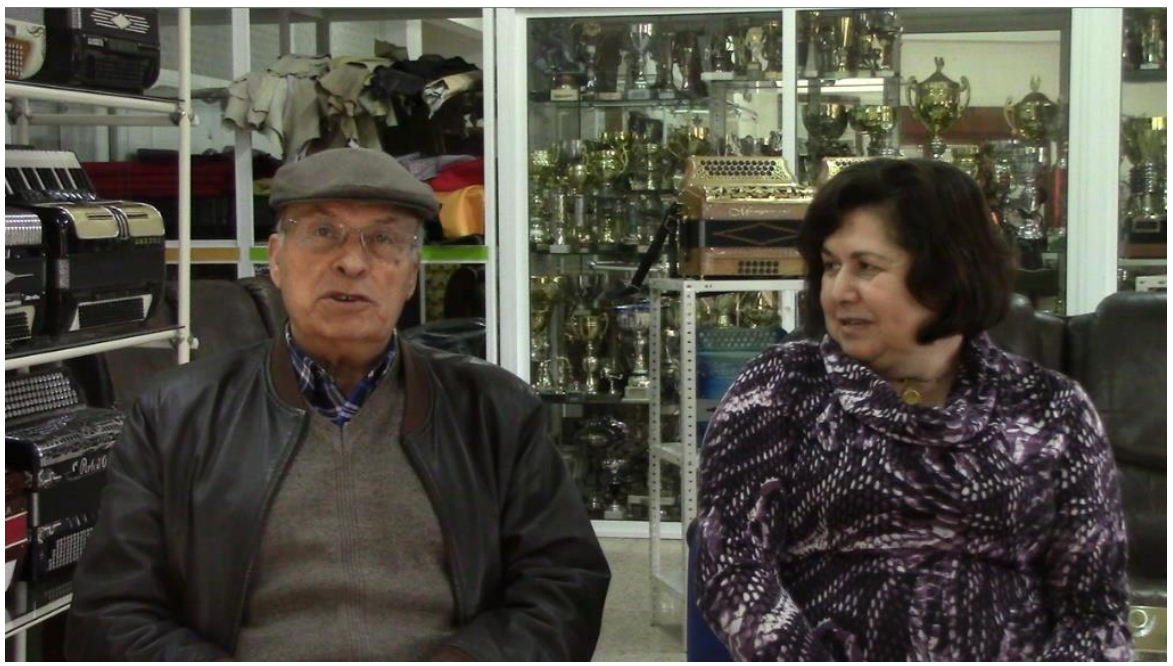

Figure 5 - Leonel Rocha and Isabel Gomes (Ferreira do Zêzere, 2020) Photo: José A Curbelo

As mentioned earlier, in considering the concertina tradition of northern Portugal, the Portuguese migratory diaspora must be taken into account to fully begin to comprehend the meanings of Memory and Identity assigned to this tradition by its practitioners, both in Portugal and abroad. The phenomenon of emigration has been a constant throughout Portuguese modern history, with different cycles of migration varying according to shifting colonial and politicoeconomic factors. Throughout these different cycles, the northern interior of the country, which includes Minho, has been a key protagonist in providing human capital to embark on migratory ventures. Motivations for migration have been primarily for economic reasons, but colonial migration, and politically-motivated migration have also been very important.

Up until the mid- $20^{\text {th }}$ century the focus of migration were the Americas, particularly Brazil, as well as migration to Portugal's African colonies. The 1950's and 60's saw a shift of migration to Western Europe, which included clandestine emigration to France to evade the draft to fight in Portugal's Colonial War during the Estado Novo. Return migration has also been a constant dynamic in Portugal, with Portuguese returning to their places of origin during certain periods: economic crises, decolonization turmoil in former colonies, etc.

This diversity of migratory movement throughout modern history up until the $21^{\text {st }}$ century has created a global diaspora of Portuguese and Luso-descendants that ascribe value to maintaining cultural and material ties to Portugal (particularly to their specific places of origin) as part of their own internal and collective processes of Identity and Memory. Carlos Pedrosa 
notes that seventy percent of his concertina sales are outside of Portugal - wherever there are Portuguese emigrants: Venezuela, Argentina, Brazil, Canada, etc. According to him, many began to play the concertina abroad out of homesickness for Portugal and the need to fraternize with other Portuguese emigrants, originating from all regions of the country. Pedrosa explains:

The folkloric groups used to have a hard time finding concertina players, few people played. Now there are a lot, here and abroad. Just in Paris, there must be five hundred concertina players. Worldwide, there could be a million Portuguese that play concertina: in Portugal, Switzerland, France, America, Canada [...] I think that it is the emigrant's homesickness ("saudade") that leads them to play the concertina. They are homesick for Portugal, for their homeland. The Portuguese emigrant abroad plays the concertina more than we do in Portugal. [...] Young and old people dance and sing, and they play (the concertina) [...] The Portuguese value it more abroad than here in Portugal, not just the concertina, its everything, because they miss their homeland. [...] People have ended up in every country. (PEDROSA, 2020)

The concertina tradition of northern Portugal is also not officially declared as Cultural Heritage by the Portuguese Government's Direção-Geral do Património Cultural though there have been attempts at including elements of the tradition in candidacies for declaration of Intangible Cultural Heritage by UNESCO. The attempts have focused on the improvised poetry tradition of canto ao desafio or canto à desgarrada, a tradition in which the concertina plays a key role in accompaniment of the improvising poets. An unsuccessful binational (Spain/Portugal) candidacy which included the tradition within a larger field of "GalicianPortuguese oral tradition" was fielded in 2005, and recently there has been discourse on behalf of Portuguese popular musical artists of presenting a candidacy to specifically declare canto ao desafio as Intangible Cultural Heritage by UNESCO. ${ }^{16}$

In comparing the case studies of these two Portuguese musical expressions found along the Luso-Spanish border: the chromatic accordion tradition of Algarve in the south, and the concertina tradition of Minho in the north, we can identify contrasts and similarities. Though neither tradition has been officially declared as national intangible cultural heritage, they enjoy relatively widespread popular support from the public. This popularization could be partly due to the residual effects of long-term government support and projection of regional folk traditions utilizing accordion and concertina during the extended period of authoritarian rule under the Estado Novo.

Both instruments have evolved to become powerful emblems of cultural identity of their respective regions: chromatic accordion in Algarve and concertina in Minho, as well as symbols representing Portugal as a whole on the international plane. Along the Luso-Spanish border

\footnotetext{
${ }^{16}$ https://correiodominho.pt/noticias/augusto-canrio-queremos-os-cantares-ao-desafio-reconhecidos-comopatrimnio-da-unesco/127346
} 
these free-reed instruments become markers of Portuguese identity vis-à-vis neighboring Spain, a nation which outwardly projects strong regionalist musical identities such as Galician traditional bagpipe music in the north and Flamenco in the south. In this sense, the chromatic accordion and concertina have become entrenched as symbolic bastions of Portuguese identity contrasted against the Spanish (or Galician, or Andalusian) "Other" on the opposing bank of the river, a continuation of the historical cultural divide associated with "La Raya".

Both the Algarvian chromatic accordion tradition and the Minho concertina tradition have been profoundly marked by each region’s respective migratory diaspora, conversely, these migratory diasporas have been marked by these musical traditions, transforming the chromatic accordion and concertina into portable symbolic vehicles of expression of regional and national Identity and Memory. In diaspora, these bellowed instruments become the catalysts to articulate socialization and ludic/cultural interaction of Portuguese migrants and Luso-descendants who - in their get-togethers, events and festivals - attempt to evoke or recreate their places of origin (real or imagined). In a sense, for these collectivities spread across the world map, Portugal can be found in the interior of an accordion or a concertina.

In relation to each tradition's transmission and projection abroad, whereas the Algarvian formal education tradition of the chromatic accordion has produced virtuosi who gain recognition for their region and their nation on international stages and in competitions inspiring new generations of accordionists - the Minho concertina tradition seems to have grown and spread due to the instrument's special capacity to serve as a catalyst for social and ludic interaction in the form of dance, improvised poetry, etc. The large migratory diaspora of northern Portugal, a region that historically has massively participated in the Portuguese vocation of emigration, and the relatively less difficult execution of the concertina has led to a proliferation of concertina players both in Portugal and abroad.

Initially calling attention to the linkages and parallels with border regions in southern South America, in this paper we have been able to reveal the processes of development and transmission of two emblematic, accordion-based musical traditions found in the border region of Portugal, we explored the dynamics through which they have been construed as regional and national markers of identity, as well as briefly reviewed efforts to declare and manage elements of those traditions as Cultural Heritage. We compared and contrasted the trajectories of these two traditions in their roles as vehicles of regional and Portuguese identity both in the context of Luso-Spanish border regions along "La Raya", as well as within the global Portuguese migratory diaspora. 
This text invites for further research into the connections between the regional accordion and concertina traditions of Portugal and similar traditions worldwide, most specifically in southern South America. The methodology of oral history has proven effective in this research, because it is precisely people's own visceral lived memories that can provide the most insight into the workings of these fluid cultural expressions, especially in the context of global migration, where, in this case, people have migrated carrying their cultural Identity and Memory with them on their backs, inside an accordion or a concertina.

\section{Interviews}

ANICETO, José Manoel (2020) Interview [Electronic recording]. Santa Bárbara de Nexe, Faro, Portugal: Independent research.

CARREIRA ROCHA, Leonel and Isabel Gomes, Bruno Gomes (2020) Interview [Electronic recording]. Ferreira do Zêzere, Santarém, Portugal: Independent research.

CONCEIÇÃO, Nelson and friends (2020) Interview [Electronic recording]. Bordeira, Sta. Bárbara de Nexe, Faro, Portugal: Independent research. (Complete list: Rui Vargues, Joaquim Farias, Joaquim Zé "Campeão" Contreiras Gago)

PEDROSA, Carlos Pedrosa (2020) Interview [Electronic recording]. Valença do Minho, Viana do Castelo, Portugal: Independent research.

PEREIRA, João Pereira (2020) Interview [Electronic recording]. Castro Marim, Faro, Portugal: Independent research.

PEREIRA, Miguel (2019) Interview [Electronic recording]. Vale do Pereiro, Castro Marim, Faro, Portugal: Independent research.

\section{References}

BLANCO ROTEA, R., GARCÍA RODRÍGUEZ, S. Paisaje arquitecturado y arquitectura en el paisaje: La fortificación del territorio en época moderna en el Baixo Miño. ArqueoWeb Revista sobre Arquelogía en Internet. Madrid: Universidad Complutense de Madrid. 7(2) sept./dic. 2005. Available at: https://webs.ucm.es/info/arqueoweb/pdf/7-2/blanco.pdf

BORGES, M. Chains of Gold: Portuguese migration to Argentina in Transatlantic perspective. Boston: Brill, 2009. 
CALDERÓN VÁZQUEZ, F. Repasando la frontera hispano-portuguesa: Conflicto, interacción y cooperación transfronteriza. Estudios Fronterizos. Mexicali: Universidad Autónoma de Baja California, Vol. 16. N.31, 2015 pp.65-89

CAMPOS INÁCIO, N. O Acordeão no Algarve: Um século de histórias e memorias. Albufeira: Arandis Editora, 2016.

CARREIRAS, H.; MALAMUD, A.; PADILLA, B.; XAVIER, M.; BUSSOLA, D. Do Fado ao Tango: A emigração portuguesa para a Região Platina. Sociologia, Problemas e Práticas, Lisboa, n.54, 2007, pp. 49-73. Available at: http://www.scielo.mec.pt/pdf/spp/n54/n54a04.pdf CURBELO, José Andreas. Dinámicas transfronterizas en la música de acordeón y bandoneón del norte uruguayo. RELACult - Revista Latino-Americana de Estudos em Cultura e Sociedade, [S.1.], v. 3, dez. 2017. ISSN 2525-7870. Available at: <http://periodicos.claec.org/index.php/relacult/article/view/615>.

CUNHA, H. Acordeão! Acordeão! Quando chegaste a Portugal? Que portas escolheste? In: MARREIROS, G.; SANCHO, E. (Coord.) Sombras e Luz: O Algarve no século XIX. São Brás de Alportel: Casa Cultura António Bentes, 2010, pp.104-113.

DIVISÃO DE CULTURA, MUSEUS, ARQUEOLOGIA E RESTAURO A Tradição do Acordeão em Bordeira, Faro, 2016. Available at: https://cms.cmfaro.pt//upload_files/client_id_1/website_id_1/museu/A\%20tradicao\%20do\%20acordeao\%20 em\%20Bordeira.pdf

EL-SHAWAN CASTELO BRANCO, S., FREITAS BRANCO, J, Folklorizaão no Portugal: Uma perspectiva. In: EL-SHAWAN CASTELO BRANCO, S., FREITAS BRANCO, J., Vozes do Povo: A folclorização em Portugal. Lisboa: Etnográfica Press, 2003.

GARCÍA-ÁLVAREZ, J., PUENTE-LOZANO, P., A controversial natural border: The making of the Spanish-Portuguese boundary along the Minho River (1855-1866) Geoforum, 79, 2017. pp.5-19. Available at: https://www.sciencedirect.com/science/article/abs/pii/S0016718516302640?via\%3Dihub

GUALDA, E. ET AL. The border, the people and the River: development of the cross-border area between southern Spain and Portugal. Community Development Journal • Vol.48 2013, pp.23-39. Available at: 
RELACult - Revista Latino-Americana de Estudos em Cultura e Sociedade

https://www.researchgate.net/publication/272089561_The border_the_people_and the_River _development_of_the_cross-border_area_between_southern_Spain_and_Portugal

GUERREIRO, H., CONCEIÇÃO, N. Terra de Acordeão: As obras de José Ferreiro Pai \&

Filho. Santa Bárbara de Nexe: Junta de Freguesia de Santa Bárbara de Nexe / Sociedade Recreativa Bordeirense, 2014.

LÓPEZ-DAVALILLO LARREA, J. Las eurociudades rayanas: Tui / Valença, Verín / Chaves, Badajoz / Elvas, Ayamonte / Sto. Antonio Vilareal. Espacio, tiempo y forma. Serie VI, Geografía, Madrid: UNED, Tomo 8-9, 2015-2016, págs. 131-167

MARQUES ALVES, V. O povo do Estado Novo. In: NEVES, J. (Coord.) Como se faz um povo, Lisboa: Tinta da China, 2010, pp.183-194 Available at: https://www.academia.edu/1108707/O_Povo_Do_Estado_Novo

MEDINA GARCÍA, E. Orígenes históricos y ambigüedad de la frontera hispano-lusa (La Raya). Revista de Estudios Extremeños. Badajoz: Diputación de Badajoz - Centro de Estudios Extremeños, Volumen: LXII, Número: 2, pp. 713-724, 2006. Available at: https://www.dipbadajoz.es/cultura/ceex/reex_digital/reex_LXII/2006/T.\%20LXII\%20n.\%202\%202006\%20m ayo-ag/RV000827.pdf

NAVAS SÁNCHEZ-ÉLEZ, M. Aproximación a los estudios de la frontera hispano-portuguesa. Études Romanes de Brno. Brno: Masaryk University Press - Munipress , Vol.41, 2020. Available at: https://digilib.phil.muni.cz/handle/11222.digilib/142572

PASCOAl SINTRA, F.; PEREIRA, J. (Coord.) Acordeão Alm'Algarvia. Castro Marim: Câmara Municipal de Castro Marim, 2016.

PEREIRA, A. Nas voltas do corridinho... In: JERÓNIMO, R., CUNHA DUARTE, J. (Coord.) Algarve - Tradições Musicais II. Faro: Grupo Musical de Santa Maria - Casa da Cultura António Bentes, 1997. pp.93-107.

RAIMUNDO, H. A construção do Folclore em Alte. al-'ulyà, Loulé: Arquivo Municipal de Loulé, 15, 0215, pp.179-197 Available at: http://hdl.handle.net/10400.1/7166

SARDINHA, J. A Origem do Fado. Vila Verde: Tradisom, 2010.

SARDINHA, J. Braga na Tradição Musical: A Rusga de S. Vicente. Vila Verde: Tradisom, 2001. 
SARDINHA, J. Tradições musicais de Estremadura. Vila Verde: Tradisom, 2000.

SOUSA, C. Folclore e turismo: Reflexões sobre o Algarve. In: EL-SHAWAN CASTELO BRANCO, S., FREITAS BRANCO, J., Vozes do Povo: A folclorização em Portugal. Lisboa: Etnográfica Press, 2003.

\section{Thanks to:}

Programa Institucional de Internacionalização - Coordenação de Aperfeiçoamento de Pessoal de Nível Superior, Universidad de Cádiz

João Pereira, Nelson Conceição, Mito Algarvio, and Nuno Loureiro 